\title{
Profile of semaglutide in the management of type 2 diabetes: design, development, and place in therapy
}

This article was published in the following Dove Medical Press journal: Drug Design, Development and Therapy

\section{Fernando Gomez-Peralta Cristina Abreu \\ Endocrinology and Nutrition Unit, Hospital General de Segovia, Segovia, Spain}

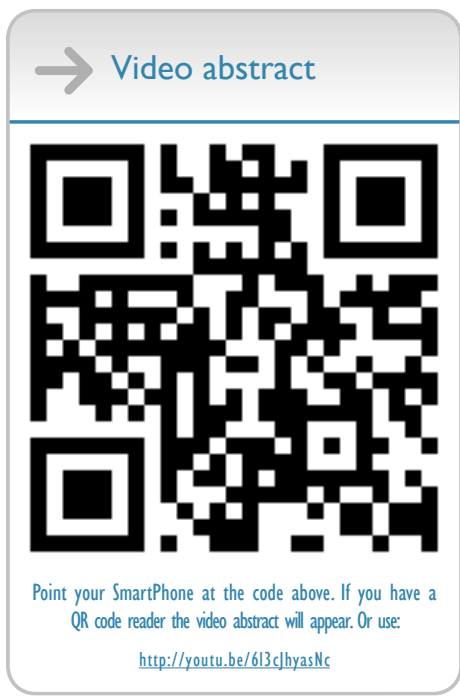

Correspondence: Fernando Gomez-Peralta

Endocrinology and Nutrition Unit, Hospital General de Segovia, Calle Luis Erik Clavería Neurólogo, S/N, 40002 Segovia, Spain

Tel +3492 I4I 9100

Fax +34 92 I4। 9149

Email fgomezperalta@gmail.com

\begin{abstract}
Type 2 diabetes mellitus (T2DM) has become one of the leading causes of morbidity and mortality in developed countries. Low efficacy, weight gain, and hypoglycemia are the main pitfalls of previous treatments for T2DM. New therapies have been designed with the aim of improving the results in efficacy and quality of life. Glucagon-like peptide 1 (GLP-1) receptor agonists (GLP-1 RA) increase glucose-dependent insulin secretion, decrease gastric emptying, and reduce postprandial glucagon secretion. The last GLP-1 RA approved by the US Food and Drug Administration and European Medicines Agency was semaglutide. This review describes its pharmacology, core clinical data coming from the randomized controlled trials included in the development program, proven cardiovascular benefits, safety issues, and precautions for the use of semaglutide in special populations. Additionally, an overview of the positioning of semaglutide in T2DM therapy and practical issues regarding semaglutide initiation are offered. Keywords: semaglutide, type 2 diabetes, pharmacological treatment, safety, clinical practice
\end{abstract}

\section{Introduction}

Diabetes mellitus (DM) has become one of the leading causes of morbidity and mortality in developed countries. ${ }^{1}$ It has also become one of the main sections of the health systems' budget. ${ }^{2}$ The term DM includes, in fact, a long list of diverse diseases characterized by the presence of hyperglycemia. However, most cases can be diagnosed as type 1 (T1DM) and type 2 (T2DM) DM. ${ }^{3}$ T2DM is a complex disease with a progressive course. Obesity, linked to insulin resistance, is the basis where relative insulin deficiency and other physiopathological alterations promote the development of metabolic and cardiovascular (CV) alterations. ${ }^{4}$ It is also the most challenging problem to manage in clinical practice, significantly conditioning therapeutic adherence. Aggravating the above mentioned challenges, the classic treatments for T2DM (sulfonylurea [SU] and insulin) are associated with clinically relevant weight increases. ${ }^{5}$

Possibly, the second most significant barrier to achieve glycemic control objective in T2DM is the risk of hypoglycemia. Hypoglycemia events represent a tremendous cost burden in terms of quality of life, morbidity, and mortality. ${ }^{6-8}$ Furthermore, SU and insulin are the most frequent causes of hypoglycemia. ${ }^{9}$

In recent years, new treatments have been developed with the aim of improving the results in efficacy and quality of life in people with T2DM. ${ }^{10}$ Incretin agents, including dipeptidyl peptidase-4 (DPP-4) inhibitors and glucagon-like peptide 1 (GLP-1) receptor agonists (GLP-1 RA), improve glucose control through several mechanisms, 
including the increase of glucose-dependent insulin secretion, decrease of gastric emptying, and reduction of postprandial glucagon secretion. ${ }^{11}$

The last GLP-1 RA approved by the US Food and Drug Administration and European Medicines Agency has been semaglutide. ${ }^{12}$ This review describes its pharmacology, core clinical data coming from the randomized controlled trials (RCTs) included in the development program, proven $\mathrm{CV}$ benefits, safety issues, and precautions for the use of semaglutide in special populations. Additionally, an overview of the positioning of semaglutide in T2DM therapy and practical issues regarding semaglutide initiation are offered.

\section{Pharmacology and characteristics of the device}

The efficacy and safety demonstrated by liraglutide were the basis for the development of semaglutide. ${ }^{13}$ After testing several molecules, in search of increasing their half-life to achieve a more convenient dosage, semaglutide was chosen. The differences in the structure between liraglutide and semaglutide were the Ala to Aib substitution in position 8, a longer linker ( $\gamma$ Glu-2xOEG vs $\gamma \mathrm{Glu}$ ), and an increase in the length of the fatty diacid chain from C16 to C18. It maintains 94\% homology with human GLP-1. The affinity of semaglutide $(0.38 \pm 0.06 \mathrm{nM})$ toward the GLP-1 receptor was reduced by three times compared to liraglutide, while affinity with albumin was increased by 5.6 times. ${ }^{12}$ This property confers a half-life of $165-184$ hours $^{14}$ ( $~ 7$ days) (Figure 1), ${ }^{15}$ with a mean time for the maximum concentration (Tmax) of 24-36 hours. ${ }^{16}$

This long duration allows a weekly administration of semaglutide with doses that were established in preclinical

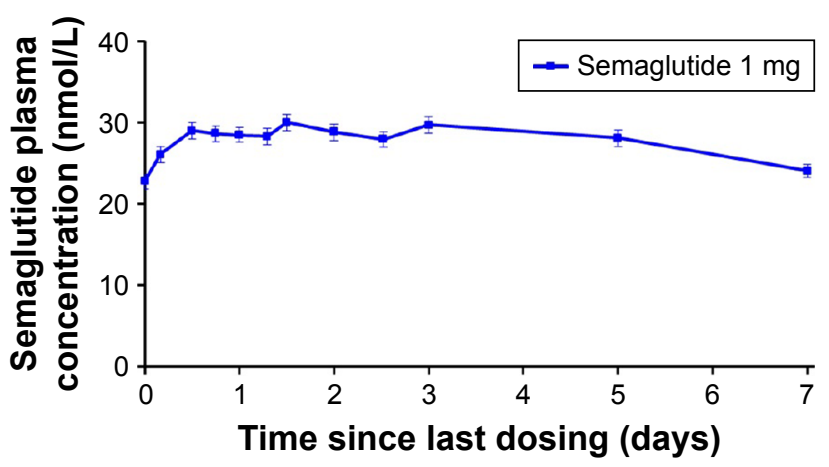

Figure I Pharmacokinetic profile during a semaglutide I $\mathrm{mg}$ dosing interval at steady state in patients with T2D.

Notes: Reproduced from FDA Briefing Document. Endocrinologic and Metabolic Drugs Advisory Committee Meeting. October 18, 2017. Semaglutide s.c. OW NDA 209637. Available from: https://www.fda.gov/downloads/advisorycommittees/ committeesmeetingmaterials/drugs/endocrinologicandmetabolicdrugsadvisory committee/ucm580460.pdf. Accessed October 9, 2018. ${ }^{15}$

Abbreviation: T2D, type 2 diabetes mellitus. studies in adults with T2DM. ${ }^{17}$ The starting dose of onceweekly semaglutide is $0.25 \mathrm{mg}$. It should be increased to $0.5 \mathrm{mg}$ after 4 weeks and can be further increased to $1 \mathrm{mg}$ if required after at least 4 weeks. ${ }^{12}$ As semaglutide is a prolonged-release GLP-1 RA, it can be administered without regard to meals. Likewise, it was verified that the presence of renal or hepatic insufficiency does not significantly alter the bioavailability of semaglutide. ${ }^{18,19}$ The Jensen et al's study on people with hepatic impairment included an exploratory linear regression analysis to examine the influence of the serum albumin on overall semaglutide exposure, and the result does not show any significant correlation ( $R=-0.012, P=0.97) .{ }^{19}$

Semaglutide is excreted in the urine (mainly, in which $\sim 3 \%$ of the dose is excreted as intact semaglutide) and in the feces. $^{20}$

Semaglutide requires selection of the dose in the injection device and removal/disposal of the needle after each injection. Semaglutide is available with three different pens for proper dosage (each box includes four of them for 1 month usage): $0.25 \mathrm{mg}$ per once weekly injection, intended for initiation during the first 4 weeks; $0.5 \mathrm{mg}$ weekly as first maintenance dose; and $1.0 \mathrm{mg}$ weekly to be used under clinical judgment in patients without gastrointestinal symptoms after at least 4 weeks with the previous dose of $0.5 \mathrm{mg}$ to further improve glycemic control.

\section{Clinical efficacy}

\section{Efficacy and safety trials: SUSTAIN I-7}

The global program of clinical trial SUSTAIN (Semaglutide unabated Sustainability in Treatment of Type 2 Diabetes) included a series of Phase IIIA RCTs (SUSTAIN 1-5), designed to evaluate the efficacy and safety of semaglutide SC administered subcutaneously once a week in a range of people with T2DM, from those who have not received drugs to those who received oral antidiabetic drugs and/or insulin. ${ }^{21-25}$

Additionally, the SUSTAIN 7 trial compared semaglutide with dulaglutide. Both are long-acting GLP-1 RAs that are administered subcutaneously once weekly. ${ }^{26}$

Main characteristics of these RCTs are summarized in Table 1.

SUSTAIN 6 is a CV safety study and has been described separately. ${ }^{27}$

\section{Effects on glycemic control}

The primary end point in the RCTs SUSTAIN 1-5 was the change in glycosylated hemoglobin $\left(\mathrm{HbA}_{1 \mathrm{c}}\right)$ from baseline until the end of the treatment. In SUSTAIN 1-5, this was calculated using the estimated averages ( \pm standard errors) 
Table I Trial design of the Phase 3 SUSTAIN I-5 and 7 trials

\begin{tabular}{|c|c|c|c|c|c|}
\hline $\begin{array}{l}\text { SUSTAIN I } \\
\text { (30 weeks) }\end{array}$ & $\begin{array}{l}\text { SUSTAIN } 2 \\
\text { (56 weeks) }\end{array}$ & $\begin{array}{l}\text { SUSTAIN } 3 \\
\text { (56 weeks) }\end{array}$ & $\begin{array}{l}\text { SUSTAIN } 4 \\
\text { ( } 30 \text { weeks) }\end{array}$ & $\begin{array}{l}\text { SUSTAIN } 5 \\
\text { ( } 30 \text { weeks) }\end{array}$ & $\begin{array}{l}\text { SUSTAIN } 7 \\
\text { (40 weeks) }\end{array}$ \\
\hline \multicolumn{6}{|l|}{ Trial design } \\
\hline $\begin{array}{l}\text { Double-blinded, placebo- } \\
\text { controlled, parallel- } \\
\text { group, multicenter, } \\
\text { multinational, four- } \\
\text { armed trial }\end{array}$ & $\begin{array}{l}\text { Double-blinded, } \\
\text { double-dummy, active- } \\
\text { controlled, parallel- } \\
\text { group, multicenter, } \\
\text { multinational, four- } \\
\text { armed trial }\end{array}$ & $\begin{array}{l}\text { Open-label, active- } \\
\text { controlled, parallel- } \\
\text { group, multicenter, } \\
\text { multinational, two- } \\
\text { armed trial }\end{array}$ & $\begin{array}{l}\text { Open-label, active- } \\
\text { controlled, parallel- } \\
\text { group, multicenter, } \\
\text { multinational, three- } \\
\text { armed trial }\end{array}$ & $\begin{array}{l}\text { Double-blinded, } \\
\text { placebo-controlled, } \\
\text { parallel-group, } \\
\text { multicenter, } \\
\text { multinational, four- } \\
\text { armed trial }\end{array}$ & $\begin{array}{l}\text { Open-label, } \\
\text { active- } \\
\text { controlled, } \\
\text { parallel-group, } \\
\text { multicenter, } \\
\text { multinational, } \\
\text { four-armed trial }\end{array}$ \\
\hline \multicolumn{6}{|l|}{ Background medication } \\
\hline None & $\begin{array}{l}\text { MET with or without } \\
\text { TZD }\end{array}$ & $\begin{array}{l}\text { One to two oral } \\
\text { antidiabetic drugs } \\
\text { (OADs) of MET, TZD, } \\
\text { or SU }\end{array}$ & MET and/or SU & $\begin{array}{l}\text { Basal insulin with or } \\
\text { without MET }\end{array}$ & MET \\
\hline \multicolumn{6}{|l|}{ Trial medication } \\
\hline $\begin{array}{l}\text { Semaglutide } 0.5 \text { or } \\
\text { I. } 0 \text { mg vs placebo } \\
\text { (all sc once weekly) }\end{array}$ & $\begin{array}{l}\text { Semaglutide } 0.5 \text { or } \\
1.0 \mathrm{mg} \text { or placebo } \\
\text { (sc once weekly) + } \\
\text { sitagliptin } 100 \mathrm{mg} \text { or } \\
\text { placebo (oral once } \\
\text { daily) }\end{array}$ & $\begin{array}{l}\text { Semaglutide } 1.0 \mathrm{mg} \text { vs } \\
\text { exenatide ER } 2.0 \mathrm{mg} \\
\text { (both sc once weekly) }\end{array}$ & $\begin{array}{l}\text { Semaglutide } 0.5 \mathrm{mg} \\
\text { or } 1.0 \mathrm{mg} \text { (sc once } \\
\text { weekly) vs insulin } \\
\text { glargine (sc once daily, } \\
\text { starting from } 10 \mathrm{IU} \\
\text { once daily) }\end{array}$ & $\begin{array}{l}\text { Semaglutide } 0.5 \text { or } 1.0 \\
\text { mg vs placebo (all sc } \\
\text { once weekly) }\end{array}$ & $\begin{array}{l}\text { Semaglutide } \\
0.5 \text { or } 1.0 \mathrm{mg} \\
\text { or dulaglutide } \\
0.75 \mathrm{mg} \text { or } \\
1.5 \mathrm{mg} \text { (both sc } \\
\text { once weekly) }\end{array}$ \\
\hline \multicolumn{6}{|l|}{ Inclusion criteria } \\
\hline $\begin{array}{l}\text { T2DM } \geq 18 \text { years on } \\
\text { treatment with diet/ } \\
\text { exercise } \\
\text { - } \mathrm{HbA}_{\mathrm{Ic}} 7.0 \%-10.0 \%\end{array}$ & $\begin{array}{l}\text { - T2DM on treatment } \\
\text { with MET or TZD } \\
\text { or MET + TZD } \\
\text { - } \mathrm{HbA}_{\mathrm{Ic}} 7.0 \%-10.5 \%\end{array}$ & $\begin{array}{l}\text { - T2DM on treatment } \\
\text { with I-2 OADs } \\
\text { (MET, TZD, } \\
\text { MET + TZD, SU) } \\
\text { - } \mathrm{HbA}_{\mathrm{Ic}} 7.0 \%-10.5 \%\end{array}$ & $\begin{array}{l}\text { - T2DM insulin-naïve } \\
\text { patients and on } \\
\text { treatment with MET } \\
\text { or MET + SU } \\
\text { - } \mathrm{HbA}_{\mathrm{Ic}} 7.0 \%-10.0 \%\end{array}$ & $\begin{array}{l}\text { - T2DM on treatment } \\
\text { with basal insulin } \\
\text { alone or in } \\
\text { combination with } \\
\text { MET } \\
\text { - } \mathrm{HbA}_{\mathrm{Ic}} 7.0 \%-10.0 \%\end{array}$ & $\begin{array}{l}\text { - } \text { T2DM on } \\
\text { treatment } \\
\text { with MET } \\
\text { monotherapy } \\
\text { - } \mathrm{HbA}_{\mathrm{lc}} \\
7.0 \%-10.5 \%\end{array}$ \\
\hline \multicolumn{6}{|l|}{ Reference } \\
\hline Sorli et $\mathrm{al}^{21}$ & Ahrén et $\mathrm{a}^{22}$ & Ahmann et $\mathrm{al}^{23}$ & Aroda et $\mathrm{a}^{24}$ & Rodbard et $\mathrm{al}^{25}$ & Pratley et $\mathrm{al}^{26}$ \\
\hline
\end{tabular}

Notes: Semaglutide Unabated Sustainability in Treatment of Type 2 Diabetes (SUSTAIN) 1-5+7 trials: NCT02054897, NCT01930188, NCT01885208, NCT02।28932, NCT0230538I, and NCT02648204. Sustain 7 column is shaded to differentiate that it is a Phase Illb study (whilst the others are phase llla).

Abbreviations: ER, extended release; $\mathrm{HbA}_{\mathrm{lc}}$, glycosylated hemoglobin; MET, metformin; sc, subcutaneous; $\mathrm{SU}$, sulfonylurea; T2DM, type 2 diabetes; TZD, thiazolidinedione.

of a mixed model for repeated measurements analysis using data of "treatment without rescue treatment" of the subjects in the full analysis set. Semaglutide showed significant and sustained reductions in $\mathrm{HbA}_{1 \mathrm{c}}$ vs comparator in all trials (Figure 2): $-1.2 \%$ to $-1.5 \%$ for the $0.5 \mathrm{mg}$ dose and $-1.5 \%$ to $-1.8 \%$ with the $1 \mathrm{mg}$ weekly dose.

In the SUSTAIN 7 trial, the $\mathrm{HbA}_{1 \mathrm{c}}$ reductions were $-1.5 \%$ and $-1.8 \%$ with 0.5 and $1 \mathrm{mg}$ dose of semaglutide, and $-1.1 \%$ and $-1.4 \%$ with 0.75 and $1.5 \mathrm{mg}$ of dulaglutide, respectively.

\section{Weight reduction}

Obesity is a key factor in the etiology of the T2DM. Weight gain is associated with increased $\mathrm{CV}$ risk and a reduction in life expectancy. ${ }^{28,29}$

Semaglutide was associated with significant reductions in weight against the comparator across SUSTAIN 1-5 program: -3.5 to $-4.3 \mathrm{~kg}$ for the $0.5 \mathrm{mg}$ dose and -4.5 to $-6.4 \mathrm{~kg}$ with the $1 \mathrm{mg}$ weekly dose (Figure 3 ). In the case of semaglutide $1.0 \mathrm{mg}$, the weight loss was at least double that of the respective comparator in each trial.

The differences in weight reduction against each comparator were: -2.5 and $-3.5 \mathrm{~kg}$ vs placebo, -1.4 and $-4.2 \mathrm{~kg}$ vs sitagliptin, and -4.7 and $-6.4 \mathrm{~kg}$ vs insulin glargine with 0.5 and $1 \mathrm{mg}$ doses of semaglutide, respectively; only the dose of $1 \mathrm{mg}$ weekly was tested against exenatide ER $2 \mathrm{mg}$ weekly and the difference was $-3.7 \mathrm{~kg}$. In the SUSTAIN 7 trial, the weight reductions were $-4.6,-6.5,-2.3$, and $-3 \mathrm{~kg}$ with the $0.5 \mathrm{mg}, 1 \mathrm{mg}$ dose of semaglutide and $0.75,1.5 \mathrm{mg}$ of dulaglutide, respectively.

Body composition changes induced by semaglutide were assessed by air displacement plethysmography after 12 weeks of treatment (weight loss $4-5 \mathrm{~kg}$ ). ${ }^{30}$ Three times greater loss of fat mass than lean body mass was observed. In a similar study by Blundell et al, appetite reduction was 


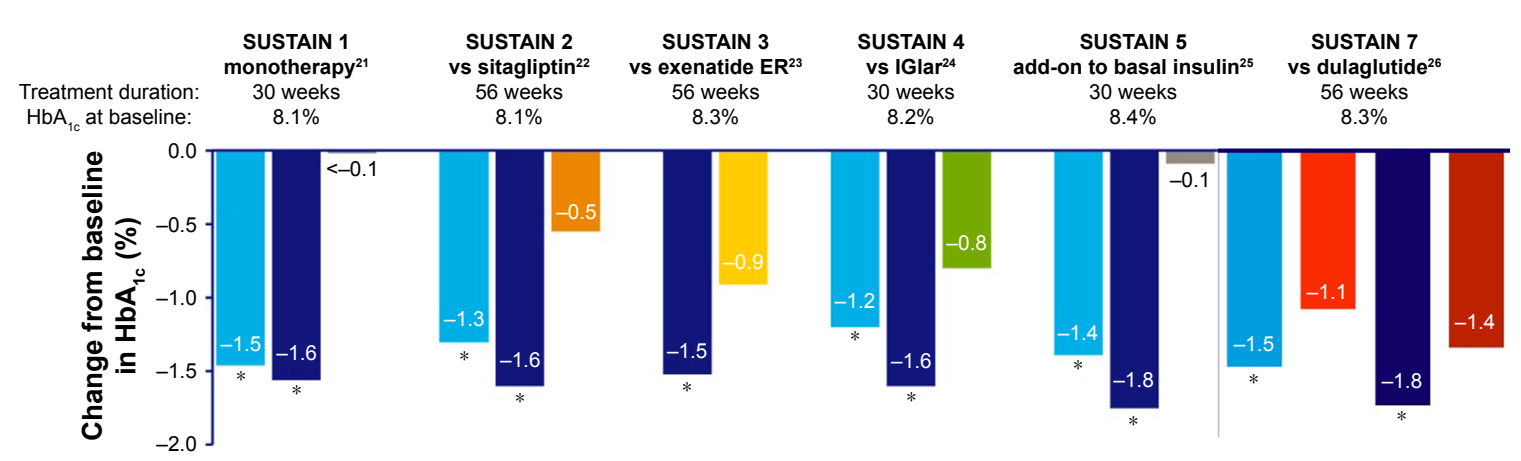

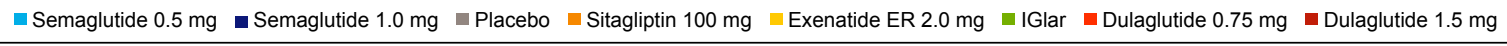

Figure 2 Change in $\mathrm{HbA}_{\mathrm{lc}}$ in SUSTAIN I-5 and 7 RCTs.

Note: $* P<0.0001$ vs comparator.

Abbreviations: ER, extended release; $\mathrm{HbA}_{1 \mathrm{c}}$, glycosylated hemoglobin: IGlar, insulin glargine; RCTs, randomized controlled trials.

described as a possible mechanism of body weight loss, which led to lower daily energy intake (decrease of $24 \%$ ), while there was no evidence that semaglutide increased the energy expenditure. Semaglutide also improved the perceived control of diet and a relatively lower preference for high-fat foods. When compared to placebo, there was no difference in the rate of nausea during meals as a possible cause for markedly reduced energy intake with semaglutide.

\section{Effects on blood pressure}

The increase in blood pressure is a risk factor for $\mathrm{CV}$ morbidity and mortality in subjects with T2DM, and its reduction has shown clinical benefits for people with T2DM. ${ }^{31}$

Semaglutide was associated with sustained reductions in SBP from the beginning through the SUSTAIN program (Figure 4). ${ }^{21-26}$

With the exception of SUSTAIN 1 trial, ${ }^{21}$ which included subjects without prior treatment and with relatively short duration T2DM, and SUSTAIN 7 trial (comparing dulaglutide), both dose levels of semaglutide were associated with significant reductions in SBP vs the comparator: -2.4 to $-5.1 \mathrm{mmHg}$ and -2.7 to $-7.3 \mathrm{mmHg}$ with the $0.5 \mathrm{mg}$ and $1 \mathrm{mg}$ weekly dose, respectively.

DBP was generally reduced with semaglutide. However, there were no significant differences when compared to the comparators.

\section{Cardiovascular and renal benefits: SUSTAIN 6 trial}

Based on recent ADA-EASD 2018 guidelines, addition of an agent with the evidence of $\mathrm{CV}$ risk reduction should be considered in patients with diabetes and established $\mathrm{CV}$ disease. ${ }^{32} \mathrm{CV}$ safety was studied in the SUSTAIN 6 study, a randomized, double-blind, placebo-controlled, four-armed, parallel-group trial of 109 weeks. ${ }^{27}$ Additional glucoselowering medication could be added to achieve glycemic control at the discretion of the investigators. Semaglutide reduced the risk of primary outcome by $26 \%$ vs placebo,

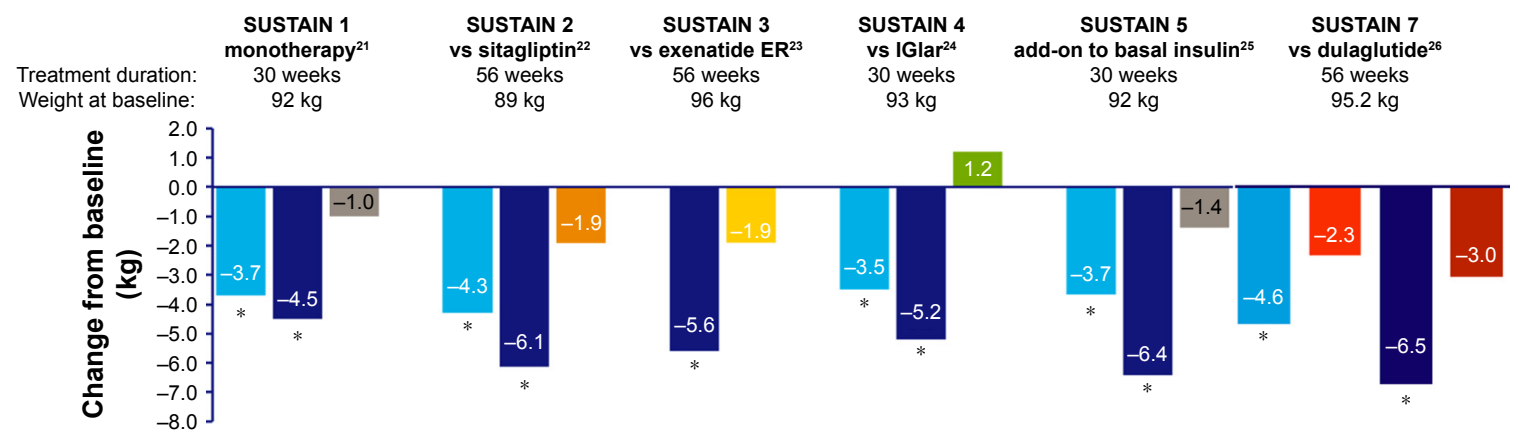

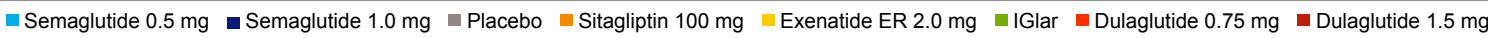

Figure 3 Change in weight in SUSTAIN I-5 and 7 RCTs.

Note: $* P<0.0001$ vs comparator.

Abbreviations: ER, extended release; IGlar, insulin glargine; RCTs, randomized controlled trials. 


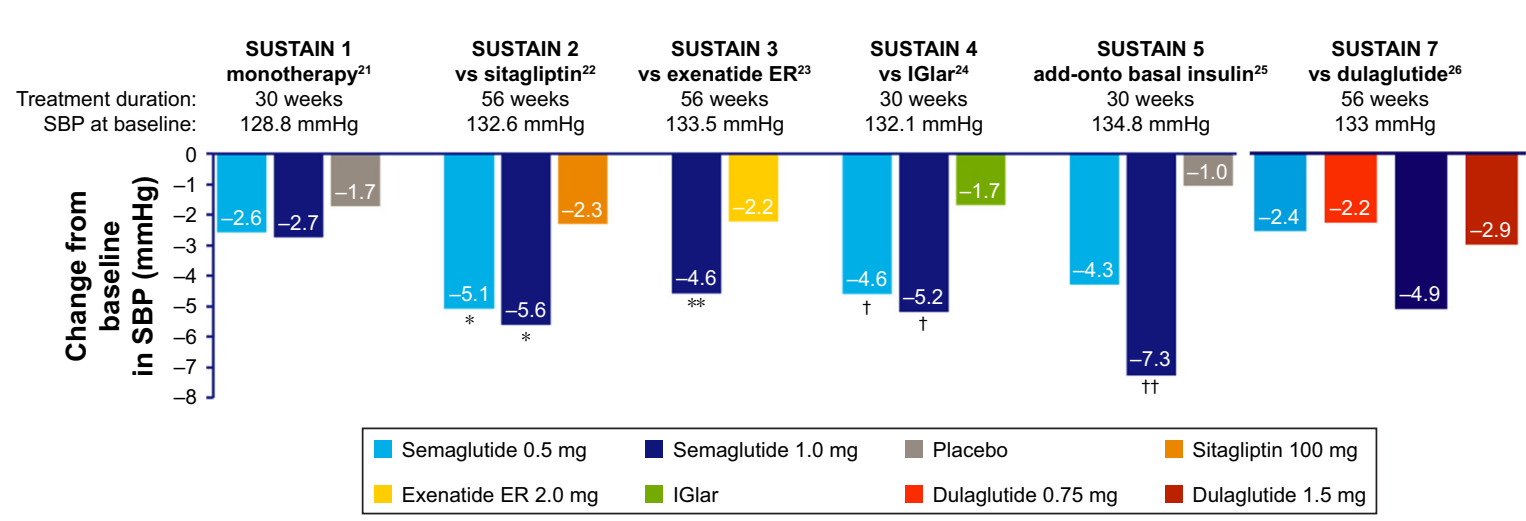

Figure 4 Change in systolic blood pressure in SUSTAIN I-5 and 7 RCTs.

Notes: $* P<0.005$ vs comparator; ${ }^{* *} P<0.02$ vs comparator; ${ }^{t} P<0.004$ vs comparator; ${ }^{+t} P<0.00$ I.

Abbreviations: ER, extended release; IGlar, insulin glargine; RCTs, randomized controlled trials.

nonfatal stroke by $39 \%$, and nonfatal myocardial infarction by $26 \%$. No difference in CV death was observed.

Additionally, the risk of new or worsening nephropathy (defined as persistent macroalbuminuria, a persistent doubling of the serum creatinine level and a creatinine clearance of $<45 \mathrm{~mL} / \mathrm{min} / 1.73 \mathrm{~m}^{2}$, or the need for continuous renal-replacement therapy) was significantly lower with semaglutide vs placebo (-36\%). Differences in macroalbuminuria drove this effect.

Semaglutide resulted in reductions in $\mathrm{HbA}_{1 \mathrm{c}}(-0.7 \%$ in the group receiving $0.5 \mathrm{mg}$ and $-1.0 \%$ in the group receiving $1.0 \mathrm{mg}$ ) and body weight $(-2.9 \mathrm{~kg}$ in the group receiving $0.5 \mathrm{mg}$ and $-4.3 \mathrm{~kg}$ lower in the group receiving $1.0 \mathrm{mg}$ ) vs placebo, with similar rates of hypoglycemia between the groups.

\section{Indications}

Semaglutide is indicated as monotherapy, when there is inadequate glycemic control with diet/exercise and when metformin is considered inappropriate due to intolerance or contraindications, and in combination with other glucoselowering medication(s), including insulin, when these together with diet and exercise - do not provide adequate glycemic control. ${ }^{12}$

\section{Administration in combination with oral antidiabetic drugs}

Just as with other GLP-1 RAs, if semaglutide is administered in combination with a $\mathrm{SU}$, a reduction in the dose of the $\mathrm{SU}$ should be considered, to reduce the risk of hypoglycemia. ${ }^{12}$

\section{Administration in combination with insulin}

In general, when semaglutide is administered in combination with basal insulin, it is recommended that a reduction in the dose of basal insulin should be considered to reduce the risk of hypoglycemia. ${ }^{12}$ In the RCT SUSTAIN 5 (addition of semaglutide to basal insulin), the dose of insulin was reduced by $20 \%$ at randomization in patients with $\mathrm{HbA}_{1 \mathrm{c}}<8 \% .{ }^{25}$

\section{Safety issues and precautions for the use of semaglutide in special populations}

The more frequent adverse events associated with the use of GLP-1 RA were gastrointestinal reactions, such as nausea, vomiting, and diarrhea. They could be especially disturbing when treating patients with impaired renal function and dehydration. Nausea occurred in $17.0 \%$ and $19.9 \%$, diarrhea in $12.2 \%$ and $13.3 \%$, and vomiting in $6.4 \%$ and $8.4 \%$ of patients when treated with semaglutide $0.5 \mathrm{mg}$ and $1 \mathrm{mg}$, respectively. ${ }^{12}$ Most events were mild to moderate in severity and led to treatment discontinuation in $3.9 \%$ and $5 \%$ of patients, respectively.

Semaglutide should be discontinued if pancreatitis is suspected and caution should be exercised in patients with a history of pancreatitis.

As described with other GLP-1 RAs, pulse rate increased in all treatment groups, with higher increases for semaglutide vs comparators $(1.7,2.5$ vs $0.4 \mathrm{bpm}$ with semaglutide $0.5 \mathrm{mg}$, $1.0 \mathrm{mg}$ vs comparator). ${ }^{33}$ The real clinical significance of this finding is currently unknown.

Only in the SUSTAIN 6 study, the risk of retinopathy complications (vitreous hemorrhage, blindness, or conditions requiring treatment with an intravitreal agent or photocoagulation) was significantly higher vs placebo (HR, 1.76). ${ }^{27}$ Rapid improvement in glucose control has been associated with a worsening of diabetic retinopathy. ${ }^{34} \mathrm{~A}$ previous ophthalmological exam and specific follow-up (depending on individual metabolic and ophthalmologic situation) are advisable when semaglutide is initiated in patients treated with insulin and with a history of diabetic retinopathy or previous poor control (Table 2). ${ }^{15}$ 
Table 2 Semaglutide as a helpful choice in challenging clinical scenarios ${ }^{\mathrm{a}}$

\begin{tabular}{|c|c|c|c|}
\hline $\begin{array}{l}\text { Clinical scenario } \\
(\text { ADA 20|8) }\end{array}$ & Concomitant treatment adjustment & Safe considerations & $\begin{array}{l}\text { Observation (data for } \\
\text { semaglutide I } \mathrm{mg} \text { ) }\end{array}$ \\
\hline $\begin{array}{l}\text { Diagnosis with } \\
\mathrm{HbA}_{\mathrm{Ic}}>9 \%\end{array}$ & $\begin{array}{l}\text { If } \mathrm{BP}<140 / 80 \mathrm{mmHg} \text {, review and decrease } \\
\text { the antihypertensive treatment according } \\
\text { to weekly monitoring }\end{array}$ & $\begin{array}{l}\text { - Information for reducing } \mathrm{Gl} A \mathrm{As}^{\mathrm{b}} \\
\text { - } \mathrm{BP} \text { monitoring } \\
\text { - Review and follow DRP'5 }\end{array}$ & $\begin{array}{l}\text { Probably reach } \mathrm{HbA}_{\mathrm{lc}} \text { target: } \\
>35 \% \mathrm{HbA}_{\mathrm{lc}}<7 \% \text { in } \\
6 \text { months }^{21}\end{array}$ \\
\hline $\begin{array}{l}\text { Not at target on dual } \\
\text { or triple oral therapy }\end{array}$ & $\begin{array}{l}\text { - Withdraw DPP4i } \\
\text { - Withdraw or reduce SU } \\
\text { - Monitoring and adjusting antihypertensive } \\
\text { treatment }\end{array}$ & $\begin{array}{l}\text { - Information for reducing GI AEs } \\
\text { - BP monitoring } \\
\text { - Review and follow DRP }\end{array}$ & $\begin{array}{l}\text { Mean } \mathrm{HbA}_{\mathrm{lc}} \text {, weight, and SBP } \\
\text { reduction ( } 56 \text { weeks): }-1.5 \% \text {, } \\
-5.6 \mathrm{~kg},-4.6 \mathrm{mmHg}^{23} \\
\text { Probably reach } \mathrm{HbA}_{\mathrm{lc}} \text { target: } \\
67 \% \mathrm{HbA}_{\mathrm{lc}}<7 \% \\
(56 \text { weeks) })^{23}\end{array}$ \\
\hline $\begin{array}{l}\text { Patient with ASCVD } \\
\text { not yet on an agent } \\
\text { with evidence of CV } \\
\text { risk reduction }\end{array}$ & $\begin{array}{l}\text { - Withdraw DPP4i } \\
\text { - Withdraw or reduce SU } \\
\text { - } \mathrm{HbA}_{\mathrm{lc}}<8 \%(69 \mathrm{mmol} / \mathrm{mol}) \text {, reduce daily } \\
\text { insulin dose by } 20 \%\end{array}$ & $\begin{array}{l}\text { - Information for reducing GI AEs }{ }^{\mathrm{b}} \\
\text { - Monitoring SMBG to prevent } \\
\text { hypoglycemia } \\
\text { - BP monitoring } \\
\text { - Review and follow DRP'5 }\end{array}$ & $\begin{array}{l}-16 \% \mathrm{RR} \text { reduction in } \\
\mathrm{CV} \text { death, nonfatal } \mathrm{MI} \text {, or } \\
\text { nonfatal stroke }{ }^{27}\end{array}$ \\
\hline $\begin{array}{l}\mathrm{HbA}_{\mathrm{Ic}} \text { not controlled } \\
\text { under basal insulin }\end{array}$ & $\begin{array}{l}\text { - } \mathrm{HbA}_{\mathrm{lc}}<8 \%(69 \mathrm{mmol} / \mathrm{mol}) \text {, reduce daily } \\
\text { insulin dose by } 20 \% \\
\text { - Withdraw DPP4i } \\
\text { - Withdraw or reduce SU }\end{array}$ & $\begin{array}{l}\text { - Information for reducing GI AEs }{ }^{\mathrm{b}} \\
\text { - Monitoring SMBG to prevent } \\
\text { hypoglycemia } \\
\text { - BP monitoring } \\
\text { - Review and follow DRP'5 }\end{array}$ & $\begin{array}{l}\text { Mean } \mathrm{HbA}_{\mathrm{lc}} \text {, weight, and SBP } \\
\text { reduction }(30 \text { weeks): }-1.8 \% \\
(20.2 \mathrm{mmol} / \mathrm{mol}),-6.4 \mathrm{~kg}, \\
\text { and }-6.3 \mathrm{mmHg}^{25} \\
\text { Probably reach } \mathrm{HbA} \mathrm{lc}_{\mathrm{c}} \text { target: } \\
79 \% \mathrm{HbA}_{\mathrm{lc}}<7 \%\left(30 \text { weeks }{ }^{25}\right. \\
\text { Mean insulin dose } \\
\text { reduction: }-15 \% \%\end{array}$ \\
\hline
\end{tabular}

Notes: a Definition of challenging clinical scenarios is as described in ADA 2018 antihyperglycemic therapy in type 2 diabetes recommendations. ${ }^{35}$ bInformation to patients about managing food intake and reducing fat content. ${ }^{37}$ Consider semaglutide dose reduction. ${ }^{38}$

Abbreviations: CV, cardiovascular; DRP, diabetic retinopathy; GI, gastrointestinal; MI, myocardial infarction; SMBG, self-monitoring of blood glucose; AEs, adverse events; ADA, American Diabetes Association: $\mathrm{HbA}_{\mathrm{lc}}$, glycosylated hemoglobin; DPP4i, dipeptidyl peptidase-4 inhibitors; ASCVD, atherosclerotic cardiovascular disease; RR, relative risk.

\section{Elderly population}

Efficacy and safety of semaglutide across the SUSTAIN program (1-5 trials) in people younger and older than 65 years have been compared in a post hoc analysis. Similar reductions in $\mathrm{HbA}_{1 \mathrm{c}}$ and mean body weight with semaglutide occurred in both age groups. The safety profile was also indistinguishable, except for a higher rate of premature treatment discontinuations caused by gastrointestinal adverse events in elderly vs non-elderly patients. ${ }^{33}$ No dose adjustment was required based on age.

\section{Renal or hepatic impairment}

No dose adjustment was required for patients with mild, moderate, or severe (estimated glomerular filtration rate $\geq 15$ to $<30 \mathrm{~mL} / \mathrm{min}$ ) renal or hepatic impairment. ${ }^{12}$ Information with regard to the use of semaglutide in patients with severe hepatic impairment is limited.

\section{Conclusion and practical positioning of semaglutide in type 2 diabetes therapy}

Practical considerations on possible clinical scenarios where semaglutide could be an interesting option in the treatment of T2DM are depicted in Table 2 . These clinically challenging situations are based on the crossroads described in the American Diabetes Association algorithm for pharmacological treatment of T2DM. ${ }^{35}$ However, these situations and recommendations are similar to those found in other clinical guidelines for the treatment of T2DM. ${ }^{32,36}$ Adjustment of concomitant treatment, safety cautions, and efficacy expectancy are also detailed.

The higher potency in reducing $\mathrm{HbA}_{1 \mathrm{c}}$ compared to other GLP-1 RAs and oral agents makes semaglutide an advantageous choice for T2DM treatment, allowing to reach glycemic targets in a broad T2DM population. The clinically relevant reductions in weight and SBP along with proven $\mathrm{CV}$ benefits in the SUSTAIN 6 trial support its preferred use in persons with established $\mathrm{CV}$ disease. ${ }^{27,35}$ Gastrointestinal tolerance is the main barrier for adherence to GLP-1 RA. Information to patients about managing food intake and reducing fat content may reduce the incidence of nausea and vomiting. ${ }^{37}$ If gastrointestinal side effects are observed, dose titration should be considered, by maintaining or reducing the semaglutide dose to 0.5 or $0.25 \mathrm{mg} .{ }^{36}$

\section{Acknowledgments}

No funding or sponsorship was received for publication of this article. No writing assistance was obtained in the preparation of this manuscript. 


\section{Author contributions}

Both authors contributed toward data analysis, drafting and critically revising the paper, gave final approval of the version to be published, and agreed to be accountable for all aspects of the work.

\section{Disclosure}

Fernando Gomez-Peralta has received research support from Sanofi, Novo Nordisk, Boehringer Ingelheim, and Eli Lilly, has taken part in advisory boards for Sanofi, Novo Nordisk, and AstraZeneca Pharmaceuticals LP, and has acted as a speaker for Sanofi, Novo Nordisk, Boehringer Ingelheim, Novartis, Bristol-Myers Squibb Company, Eli Lilly, and AstraZeneca Pharmaceuticals LP. Cristina Abreu has received research support from Sanofi, Novo Nordisk, Boehringer Ingelheim Pharmaceuticals, and Lilly, and has acted as a speaker for Sanofi, Novo Nordisk, Boehringer Ingelheim Pharmaceuticals, AstraZeneca Pharmaceuticals LP, and Bristol-Myers Squibb Co. The authors report no other conflicts of interest in this work.

\section{References}

1. Kassebaum NJ, Arora M, Barber RM, et al. Global, regional, and national disability-adjusted life-years (DALYs) for 315 diseases and injuries and healthy life expectancy (HALE), 1990-2015: a systematic analysis for the global burden of Disease Study 2015. Lancet. 2016;388(10053): 1603-1658.

2. Smith-Spangler CM, Bhattacharya J, Goldhaber-Fiebert JD. Diabetes, its treatment, and catastrophic medical spending in 35 developing countries. Diabetes Care. 2012;35(2):319-326.

3. American Diabetes Association. 2. Classification and diagnosis of diabetes: Standards of Medical Care in Diabetes-2018. Diabetes Care. 2018;41(Suppl 1):S13-S27.

4. Gómez Huelgas R, Gómez Peralta F, Carrillo Fernández L, et al. Hacia un manejo integral del paciente con diabetes y obesidad. Posicionamiento de la SEMI, SED, redGDPS, SEC, SEEDO, SEEN, SEMERGEN y SEMFYC [Towards an integral management of the patient with diabetes and obesity. Position statement of the SEMI, SED, redGDPS, SEC, SEEDO, SEEN, SEMERGEN and SEMFYC]. Revista Clínica Española. 2015;215(9):505-514.

5. Balkau B, Home PD, Vincent M, Marre M, Freemantle N. Factors associated with weight gain in people with type 2 diabetes starting on insulin. Diabetes Care. 2014;37(8):2108-2113.

6. Chico A, Vidal-Ríos P, Subirà M, Novials A. The continuous glucose monitoring system is useful for detecting unrecognized hypoglycemias in patients with type 1 and type 2 diabetes but is not better than frequent capillary glucose measurements for improving metabolic control. Diabetes Care. 2003;26(4):1153-1157.

7. McCoy RG, Van Houten HK, Ziegenfuss JY, Shah ND, Wermers RA, Smith SA. Increased mortality of patients with diabetes reporting severe hypoglycemia. Diabetes Care. 2012;35(9):1897-1901.

8. Barranco RJ, Gomez-Peralta F, Abreu C, et al. Incidence and carerelated costs of severe hypoglycaemia requiring emergency treatment in Andalusia (Spain): the PAUEPAD project. Diabet Med. 2015;32(11): $1520-1526$.

9. Budnitz DS, Lovegrove MC, Shehab N, Richards CL. Emergency hospitalizations for adverse drug events in older Americans. $N$ Engl $J$ Med. 2011;365(21):2002-2012.

10. Gomez-Peralta F, Abreu Padín C, Ca P, Padín CA. Do we need new treatments for type 2 diabetes? Endocrinol Nutr. 2014;61(6):323-328.
11. Mari A, Bagger JI, Ferrannini E, Holst JJ, Knop FK, Vilsbøll T. Mechanisms of the incretin effect in subjects with normal glucose tolerance and patients with type 2 diabetes. PLoS One. 2013;8(9):e73154.

12. European Medicines Agency. Ozempic: summary of product characteristics; 2018. Available from: http://www.ema.europa.eu/docs/en_GB/ document_library/EPAR_-_Product_Information/human/004174/ WC500244163.pdf. Accessed September 3, 2018.

13. Lau J, Bloch P, Schäffer L, et al. Discovery of the once-weekly glucagon-like peptide-1 (GLP-1) analogue Semaglutide. J Med Chem. 2015;58(18):7370-7380.

14. Kapitza C, Nosek L, Jensen L, Hartvig H, Jensen CB, Flint A. Semaglutide, a once-weekly human GLP-1 analog, does not reduce the bioavailability of the combined oral contraceptive, ethinylestradiol/ levonorgestrel. J Clin Pharmacol. 2015;55(5):497-504.

15. FDA Briefing Document. Endocrinologic and Metabolic Drugs Advisory Committee Meeting. October 18, 2017. Semaglutide s.c. OW NDA 209637. Available from: https://www.fda.gov/downloads/ advisorycommittees/committeesmeetingmaterials/drugs/endocrinologicandmetabolicdrugsadvisorycommittee/ucm580460.pdf.

16. Chudleigh R, Bain SC, Semaglutide BSC. Semaglutide. GLP-1 receptor agonist, treatment of type 2 diabetes. Drugs Future. 2017; 42(8):479.

17. Nauck MA, Petrie JR, Sesti G, et al. A phase 2, randomized, dose-finding study of the novel once-weekly human GLP-1 analog, Semaglutide, compared with placebo and open-label liraglutide in patients with type 2 diabetes. Diabetes Care. 2016;39(2):231-241.

18. Marbury TC, Flint A, Jacobsen JB, Derving Karsbøl J, Lasseter K. Pharmacokinetics and tolerability of a single dose of Semaglutide, a human glucagon-like peptide- 1 analog, in subjects with and without renal impairment. Clin Pharmacokinet. 2017;56(11):1381-1390.

19. Jensen L, Kupcova V, Arold G, Pettersson J, Hjerpsted JB. Pharmacokinetics and tolerability of semaglutide in people with hepatic impairment. Diabetes Obes Metab. 2018;20(4):998-1005.

20. Jensen L, Helleberg H, Roffel A, et al. Absorption, metabolism and excretion of the GLP-1 analogue semaglutide in humans and nonclinical species. Eur J Pharm Sci. 2017;104:31-41.

21. Sorli C, Harashima SI, Tsoukas GM, et al. Efficacy and safety of onceweekly semaglutide monotherapy versus placebo in patients with type 2 diabetes (sustain 1): a double-blind, randomised, placebo-controlled, parallel-group, multinational, multicentre phase $3 \mathrm{~A}$ trial. Lancet Diabetes Endocrinol. 2017;5(4):251-260.

22. Ahrén B, Masmiquel L, Kumar H, et al. Efficacy and safety of onceweekly semaglutide versus once-daily sitagliptin as an add-on to metformin, thiazolidinediones, or both, in patients with type 2 diabetes (sustain 2): a 56-week, double-blind, phase 3A, randomised trial. Lancet Diabetes Endocrinol. 2017;5(5):341-354.

23. Ahmann AJ, Capehorn M, Charpentier G, et al. Efficacy and safety of once-weekly Semaglutide versus exenatide ER in subjects with type 2 diabetes (sustain 3): a 56-Week, open-label, randomized clinical trial. Diabetes Care. 2018;41(2):258-266.

24. Aroda VR, Bain SC, Cariou B, et al. Efficacy and safety of once-weekly semaglutide versus once-daily insulin glargine as add-on to metformin (with or without sulfonylureas) in insulin-naive patients with type 2 diabetes (sustain 4): a randomised, open-label, parallel-group, multicentre, multinational, phase 3A trial. Lancet Diabetes Endocrinol. 2017; 5(5):355-366.

25. Rodbard HW, Lingvay I, Reed J, et al. Semaglutide added to basal insulin in type 2 diabetes (sustain 5): a randomised, controlled trial. J Clin Endocrinol. 2018;1103(6):2291-2301.

26. Pratley RE, Aroda VR, Lingvay I, et al. Semaglutide versus dulaglutide Once Weekly in patients with type 2 diabetes (sustain 7): a randomised, open-label, phase 3B trial. Lancet Diabetes Endocrinol. 2018;6(4):275-286.

27. Marso SP, Bain SC, Consoli A, et al; SUSTAIN-6 Investigators. Semaglutide and cardiovascular outcomes in patients with type 2 diabetes. N Engl J Med. 2016;375(19):1834-1844. 
28. Kivimäki M, Kuosma E, Ferrie JE, et al. Overweight, obesity, and risk of cardiometabolic multimorbidity: pooled analysis of individual-level data for 120813 adults from 16 cohort studies from the USA and Europe. Lancet Public Health. 2017;2(6):e277-e285.

29. Nyberg ST, Batty GD, Pentti J, et al. Obesity and loss of disease-free years owing to major non-communicable diseases: a multicohort study. Lancet Public Health. 2018;3(10):e490-e497.

30. Blundell J, Finlayson G, Axelsen M, et al. Effects of once-weekly semaglutide on appetite, energy intake, control of eating, food preference and body weight in subjects with obesity. Diabetes Obes Metab. 2017; 19(9):1242-1251.

31. de Boer IH, Bangalore S, Benetos A, et al. Diabetes and hypertension: a position statement by the American diabetes association. Diabetes Care. 2017;40(9):1273-1284.

32. Davies MJ, D’Alessio DA, Fradkin J, et al. Management of hyperglycemia in type 2 diabetes, 2018. A consensus report by the American diabetes Association (ADA) and the European association for the study of diabetes (EASD). Diabetes Care. 2018;41(12):2669-2701.

33. Warren M, Chaykin L, Trachtenbarg D, Nayak G, Wijayasinghe N, Cariou B. Semaglutide as a therapeutic option for elderly patients with type 2 diabetes: pooled analysis of the sustain 1-5 trials. Diabetes Obes Metab. 2018;20(9):2291-2297.
34. Ting DS, Cheung GC, Wong TY. Diabetic retinopathy: global prevalence, major risk factors, screening practices and public health challenges: a review. Clin Exp Ophthalmol. 2016;44(4):260-277.

35. American Diabetes Association. 8. Pharmacologic Approaches to Glycemic Treatment: Standards of Medical Care in Diabetes-2018. Diabetes Care. 2018;41(Suppl 1):S73-S85.

36. Gomez-Peralta F, Escalada San Martín FJ, Menéndez Torre E, et al. Recomendaciones de la Sociedad Española de diabetes (SED) para el tratamiento farmacológico de la hiperglucemia en La diabetes tipo 2: Actualización 2018 [Spanish Diabetes Society (SED) recommendations for the pharmacologic treatment of hyperglycemia in type 2 diabetes: 2018 Update]. Endocrinol Diabetes Nutr. 2018;65(10):611-624.

37. Hinnen D. Glucagon-like peptide 1 receptor agonists for type 2 diabetes. Diabetes Spectr. 2017;30(3):202-210.

38. Aroda VR, Ratner R. The safety and tolerability of GLP-1 receptor agonists in the treatment of type 2 diabetes: a review. Diabetes Metab Res Rev. 2011;27(6):528-542.

\section{Publish your work in this journal}

Drug Design, Development and Therapy is an international, peerreviewed open-access journal that spans the spectrum of drug design and development through to clinical applications. Clinical outcomes, patient safety, and programs for the development and effective, safe, and sustained use of medicines are the features of the journal, which has also been accepted for indexing on PubMed Central. The manuscript management system is completely online and includes a very quick and fair peer-review system, which is all easy to use. Visit http://www.dovepress.com/testimonials.php to read real quotes from published authors.

Submit your manuscript here: http://www.dovepress.com/drug-design-development-and-therapy-journal 